\title{
PENGARUH MODEL PEMBELAJARAN KOOPERATIF TIPE THINK-PAIR-SQUARE DENGAN PENDEKATAN OPEN-ENDED TERHADAP KEMAMPUAN BERPIKIR KRITIS MATEMATIS SISWA SMA NEGERI 48 JAKARTA
}

\author{
Suci Sukmawati ${ }^{1}$, Lukman El Hakim² ${ }^{2}$, Mimi Nur Hajizah ${ }^{3}$ \\ ${ }^{1}$ Prodi Pendidikan Matematika Universitas Negeri Jakarta \\ sukmawatisuci11@gmail.com \\ ${ }^{2}$ Prodi Pendidikan Matematika Universitas Negeri Jakarta \\ mimi.nurhajizah@gmail.com \\ ${ }^{3}$ Prodi Pendidikan Matematika Universitas Negeri Jakarta \\ lukman111985@gmail.com
}

\begin{abstract}
ABSTRAK
Penelitian ini bertujuan untuk mengetahui apakah terdapat pengaruh model pembelajaran kooperatif tipe think-pair-square dengan pendekatan open-ended terhadap kemampuan berpikir kritis matematis siswa SMA Negeri 48 Jakarta. Penelitian ini adalah penelitian kuantitatif dengan metode eksperimen semu. Desain penelitian yang digunakan ialah Control-group post-test only design. Populasi penelitian ini ialah siswa SMA Negeri 48 Jakarta. Teknik pengambilan sampel menggunakan teknik cluster random sampling. Kelas X-IPS-3 sebagai kelas eksperimen dan kelas X-IPS-2 sebagai kelas kontrol. Berdasarkan hasil pengujian menggunakan uji- $t$ diperoleh rata-rata kemampuan berpikir kritis matematis siswa kelas eksperimen lebih tinggi daripada kelas kontrol. Hal ini menunjukkan bahwa terdapat pengaruh dari model pembelajaran kooperatif tipe think-pair-square dengan pendekatan open-ended terhadap kemampuan berpikir kritis matematis siswa SMA Negeri 48 Jakarta.
\end{abstract}

Kata kunci: Model Pembelajaran Kooperatif Tipe Think-Pair-Square, Pendekatan Open-Ended, Kemampuan Berpikir Kritis Matematis

\begin{abstract}
This study aims to determine whether there is an influence of the cooperative learning model type think-pair-square with open-ended approach toward students' mathematical critical thinking ability of 48 Senior High School Jakarta. This research is quantitative research with quasi-experimental methods. The research design used was Control-group post-test only design. The population of this study was students of 48 Senior High Shool Jakarta. The sampling technique uses luster random sampling technique. Class X-IPS-3 as the experimental class and class X-IPS-2 as the control class. Based on the test results using the t-test the average mathematical critical thinking ability of the experimental class students was higher than the control class. This shows that there is an influence from the cooperative learning model type think-pair-square with open-ended approach toward students' mathematical critical thinking ability of 48 Senior High School Jakarta.
\end{abstract}

Keywords: Cooperative Learning Model Type Think-Pair-Square, Open-Ended 
Approach, Mathematical Critical Thinking Ability 


\section{PENDAHULUAN}

Matematika sebagai salah satu mata pelajaran pokok sangat penting peranannya di setiap jenjang pendidikan, baik untuk kepentingan pengembangan matematika sendiri, maupun untuk aplikasi pengembangan ilmu pengetahuan dan kemajuan sains teknologi. Menurut Sabandar, belajar matematika berkaitan erat dengan aktivitas dan proses belajar serta berpikir karena karakterisitik matematika merupakan suatu ilmu dan human activity, yaitu bahwa matematika adalah pola berpikir, pola mengorganisasikan pembuktian yang logis, yang menggunakan istilah yang didefinisikan dengan cermat, jelas, dan akurat (Budiman, 2011). Hal ini menunjukkan bahwa pola berpikir bisa lebih ditingkatkan dengan adanya pembelajaran matematika.

Asosisasi Matematika mengemukakan beberapa tujuan pembelajaran matematika di sekolah salah satunya adalah melatih siswa untuk selalu berpikir sistematis, logis dan kritis dalam mengkomunikasikan gagasan, serta self-concept siswa pada lingkungan belajarnya (Rafiah dkk, 2018). Selain itu, seiring berkembangnya zaman, Indonesia mengalami perubahan kurikulum menjadi kurikulum 2013 yang diharapkan dapat membantu peserta didik meningkatkan High Order Thinking Skill (HOTS) atau kemampuan berpikir tingkat tinggi. Kemampuan berpikir kritis merupakan salah satu bagian dari kemampuan berpikir tingkat tinggi (Nugroho, 2018). Hal ini menunjukkan bahwa kemampuan berpikir kritis siswa sangat penting untuk ditingkatkan bahkan menjadi salah satu tujuan pembelajaran sekolah di Indonesia terutama untuk pembelajaran matematika.

Kemampuan berpikir kritis adalah salah satu modal penting bagi siswa dalam kehidupan sehari-hari, karena manusia selalu dihadapkan pada keadaan atau masalah yang memerlukan pemecahan. Menurut Abidin, keterampilan yang diharapkan dimiliki setiap siswa saat ini adalah lebih menitikberatkan pada keterampilan berpikir, salah satunya yaitu keterampilan berpikir kritis (Muniarti, 2015). Kemampuan berpikir kritis ber-manfaat untuk menyaring dan memilih informasi yang layak serta mampu menanyakan apakah informasi tersebut benar-benar ada atau tidak. Sehingga tidak membahayakan dalam kehidupan mereka.

Berpikir kritis di berbagai bidang memiliki karakteristik yang sedikit berbeda, bergitupula pada kemampuan berpikir kritis dalam pembelajaran matematika atau sering kali disebut berpikir kritis matematis. Glazer menyatakan bahwa berpikir kritis matematis sebagai kemampuan dan disposisi untuk menyertakan pengetahuan sebelumnya, penalaran matematika, dan strategi kognitif untuk menggeneralisasi, membuktikan, atau mengevaluasi situasisituasi matematika yang tidak familiar secara reflektif (Suwarma, 2009). Dalam hal ini siswa didorong dan dilatih secara berkala untuk menyelesaikan berbagai masalah non rutin dalam matematika agar kemampuan berpikir kritis dapat berkembang.

Beberapa tokoh yang lain mengemukakan definisi yang dapat disimpulkan bahwa kemampuan berpikir kritis matematis adalah kemampuan berpikir kritis matematis adalah kemampuan yang menggabungkan pengetahuan awal, penalaran dengan mengidentifikasi, menghubungkan, menguji, mempertanyakan, mengevaluasi semua aspek yang ada sehingga dapat memecahkan masalah matematika 
dan menghasilkan kesimpulan yang dapat dipercaya dan masuk akal.

Hasil dua studi internasional yaitu TIMSS dan PISA yang juga dapat mengukur kemampuan berpikir kritis matematis menunjukkan siswa Indonesia masih tergolong rendah terutama dalam hal menyelesaikan soal non rutin yang membutuhkan kemampuan berpikir kritis matematis.

Hal ini terjadi karena tradisi belajar untuk meningkatkan kemampuan berpikir kritis dalam matematika pada siswa di Indonesia belum diterapkan di sekolah namun masih menerapkan sistem pembelajaran konven-sional. Menurut kritikus Jacqueline dan Brooks, sedikit sekolah yang mengajarkan siswanya berpikir kritis. Sekolah justru mendorong siswa memberi jawaban yang benar daripada mendorong mereka memunculkan ideide baru atau memikirkan ulang kesimpulan-kesimpulan yang sudah ada. Akibatnya banyak sekolah meluluskan siswa-siswa yang mampu berpikir secara dangkal (Syahbana, 2012). Siswa hanya mampu menyelesaikan soal jika memuat petunjuk atau indikasi eksplisit terkait rumus, prosedur, ataupun konsep yang dibutuhkan. Perlunya diterapkan suatu strategi belajar yang dapat membantu siswa untuk memahami materi ajar dan aplikasinya serta relevan-sinya dalam kehidupan sehari-hari.

Salah satu alternatif pembelajaran yang dapat dikembangkan oleh guru dalam mewujudkan proses pembelajaran matematika yang mampu meningkatkan kemampuan berpikir kritis siswa tersebut ialah dengan menerapkan model pembelajaran kooperatif. Menurut Roger dkk, pembelajaran kooperatif merupakan aktivitas pembelajaran kelompok yang diorganisir oleh satu prinsip bahwa pembelajaran harus didasarkan pada perubahan informasi secara sosial di antara kelompok- kelompok pembe-lajar yang di dalamnya setiap pembelajar bertanggung jawab atas pembelajarannya sendiri dan didorong untuk meningkatkan pembelajaran anggota-anggota yang lain (Huda, 2011). Dalam hal ini siswa tidak hanya memerlukan akses pengalaman fisik tetapi juga interaksi dengan pengalaman yang dimiliki oleh individu lain, sehingga diperlukanlah adanya kegiatan pembelajaran yang bersifat seperti pembelajaran kooperatif yang menuntut siswa bekerja sama untuk mencapai tujuan pembelajaran.

Model pembelajaran kooperatif memiliki berbagai tipe salah satunya adalah tipe Think-pair-square (TPSq). Tipe ini memberikan kesempatan kepada siswa untuk merumuskan dan menyelesaikan masalah dalam kelompok. Model pembelajaran kooperatif tipe TPSq dikembangkan oleh Spencer Kagan. Menurut Mills, struktur TPSq ini memberikan kesempatan kepada siswa untuk mendiskusikan ide-ide mereka dan menyediakan sarana bagi mereka untuk melihat cara lain dalam menyelesaikan masalah (Sumaryati, 2012). Model pembelajaran kooperatif tipe TPSq berpotensi meningkatkan kemampuan berpikir kritis siswa dengan cara menuntut siswa berpikir sendiri pada tahap yang pertama yaitu think serta bekerja sama dengan orang lain pada tahap pair (berpasangan) dan square (berempat) untuk mendiskusikan ide-ide mereka sehingga menghasilkan jawaban yang lebih komprehensif.

Selain penggunaan model pembelajaran dengan kelompok perlu diterapkan pembelajaran yang dapat mengasah lebih kemampuan berpikir kritis matematis siswa yaitu dengan pendekatan open-ended. Menurut Brookhart dalam Koriyah bahwa kesempatan luas pada pendekatan open-ended memungkinkan siswa 
berpikir secara lebih mendalam di mana berpikir secara kritis merupakan berpikir secara mendalam dan merupakan bagian dari berpikir tingkat tinggi serta dengan jawaban yang berbeda sehingga siswa dengan kemampuan rendah dapat memberikan respon terhadap masalah dengan cara mereka sendiri secara bermakna (Koriyah 2015). Pendekatan open-ended merupakan pendekatan yang menyajikan suatu masalah terbuka (open-ended) yang memungkinkan siswa mengembangkan pola pikirnya dengan bebas sesuai dengan minat dan kemampuan masing-masing, sehingga dapat memberi kesempatan kepada siswa untuk memperoleh pengetahuan, mengenali, dan memecahkan masalah dengan beberapa teknik dan menghargai siswa ketika mereka menemukan jawaban dari masalah yang diberikan serta memperhatikan perbedaan kognitif siswa (Fahrurrozi, 2015).

Berdasarkan pada uraian diatas, model pembelajaran kooperatif tipe think-pair -square (TPSq) dengan pendekatan open-ended diduga dapat dijadikan alternatif model pembelajaran untuk meningkatkan kemampuan berpikir kritis matematis siswa. Oleh karena itu, perlu diadakan penelitian mengenai "Pengaruh Model Pembelajaran Kooperatif Tipe Think-pair-square (TPSq) dengan Pendekatan Openended Terhadap Kemampuan Berpikir Kritis Matematis Siswa SMA Negeri 48 Jakarta".

\section{METODE PENELITIAN}

Metode penelitian yang digunakan adalah quasi experiment atau eksperimen semu. Metode eksperimen semu ini adalah metode penelitian yang dilakukan atas pertimbangan ketidak-mungkinan peneliti melakukan pengontrolan secara penuh terhadap semua variable yang ada dan kondisi kelas eksperimen yang diteliti (Sugiyono, 2012). Metode ini digunakan untuk mengetahui apakah terdapat pengaruh model pembelajaran kooperatif tipe think-pair -square dengan pendekatan openended terhadap kemampuan berpikir kritis matematis siswa SMA Negeri 48 Jakarta.

Desain penelitian yang digunakan ialah Control-group post-test only design dimana terdapat dua kelompok (kelas) yang dipilih yaitu kelas eksperimen yang diberi perlakuan berupa model pembelajaran kooperatif tipe think-pair -square dengan pendekatan openended dan kelas kontrol yang diberi perlakuan pembelajaran konvensional Setelah kedua kelas tersebut memperoleh perlakuan dalam jangka waktu yang sama, selanjutnya kedua kelas tersebut akan diberikan post-test yang sesuai dengan indikator kemampuan berpikir kritis matematis. Berikut adalah tabel desain penelitian yang digunakan:

\section{Tabel 1 Desain Penelitian}

\begin{tabular}{|c|c|c|}
\hline \multicolumn{1}{|c|}{ Kelas } & Perlakuan & Tes \\
\hline Ekperimen & $\mathrm{X}$ & 0 \\
\hline Kontrol & - & 0 \\
\hline
\end{tabular}

Keterangan:

$X$ : Pembelajaran matematika dengan model pembelajaran kooperatif tipe think-pair-square dengan pendekatan open-ended

0 : Tes kemampuan berpikir kritis matematis

Variabel pada penelitian ini menggunakan dua variabel yaitu variabel bebas dan variabel terikat, dimana variabel bebasnya adalah model pembelajaran kooperatif tipe think-pair-square dengan pendekatan open-ended. Sedangkan variabel terikat pada penelitian ini adalah kemampuan berpikir kritis matematis. 
Populasi target pada penelitian ini adalah seluruh siswa di SMA Negeri 48 Jakarta. Sedangkan populasi terjangkau pada penelitian ini adalah seluruh siswa kelas X-IPS SMA Negeri 48 Jakarta yang terdiri dari 3 kelas pada semester genap tahun ajaran 2018/2019.

Pengambilan sampel pada penelitian ini menggunakan teknik cluster random sampling yaitu teknik pengambilan sampel dari populasi menjadi beberapa kelompok yang disebut cluster (Suprapto, 2013). Penggunaan teknik cluster random sampling dilakukan dengan mengambil seluruh siswa di dalam satu kelas sebagai sampel penelitian. Setelah itu terpilih dua kelas yang akan dijadikan sebagai kelas sampel penelitian. Kelas yang digunakan sebagai sampel penelitian tersebut terdiri atas kelas kontrol yang menggunakan pembelajaran konvensional dengan jumlah sampel 36 siswa dan kelas eksperimen yang belajar menggunakan model pembelajaran kooperatif tipe think-pair -square dengan pendekatan openended memiliki jumlah sampel 36 siswa.

Adapun hipotesis pada penelitian ini adalah model pembelajaran kooperatif tipe Think-pair-square dengan pendekatan open-ended memiliki pengaruh terhadap kemampuan berpikir kritis matematis siswa. Adanya pengaruh itu sendiri dapat dilihat dengan membandingkan hasil tes kemampuan berpikir kritis matematis dari kelas yang menggunakan model pembelajaran kooperatif tipe think-pair-square dengan pendekatan open-ended dan kelas yang menggunakan model pembelajaran konvensional. Jika hasil post-test dari kelas yang menggunakan model pembelajaran kooperatif tipe think-pair-square dengan pendekatan open-ended lebih tinggi dari kelas yang menggunakan model pembelajaran konvensional. Maka dapat disimpulkan bahwa model pembelajaran kooperatif tipe think-pair -square dengan pendekatan openended memberikan pengaruh terhadap kemampuan berpikir kritis matematis siswa.

Hipotesis pada penelitian ini dirumuskan sebagai berikut:

$$
\begin{array}{ll}
0: & 1 \leq 2 \\
\text { 1: } & 1>2
\end{array}
$$

Keterangan :

0 : Hipotesis nol

1 : Hipotesis tandingan

1 : Rata-rata nilai hasil tes kelas eksperimen

(kemampuan berpikir kritis matematis siswa yang belajar menggunakan model pembelajaran kooperatif tipe Think-Pair-Square dengan pendekatan open-ended)

2 : Rata-rata nilai hasil tes kelas kontrol (kemampuan berpikir kritis matematis siswa yang belajar menggunakan model pembelajaran konvensional)

Data sebelum perlakuan yang digunakan dalam penelitian ini adalah nilai Penilaian Hasil Bersama (PHB) pada materi trigonometri yang telah melalui proses uji analisis data untuk mengetahui apakah data tersebut berasal dari kelas yang berdistribusi normal, homogen, dan memiliki kesamaan rata-rata. Setelah dilakukan ketiga uji tersebut, ketiga data kelas menunjukkan bahwa berasal dari distribusi normal, homogen dan memiliki kesamaan rata-rata. Sehingga dilakukan pengambilan sampel secara cluster random sampling untuk menentukan kelas eksperimen dan kelas kontrol.

Instrumen post-test yang digunakan dalam penelitian ini adalah berupa tes kemampuan berpikir kritis matematis dengan 4 indikator. Indikator 
kemampuan berpikir kritis matematis yang digunakan pada penelitian ini adalah mengidentifikasi dan menjastifikasi masalah, menggeneralisasi, menganalisis logaritma, memecahkan masalah. Sebelum instrumen digunakan dalam penelitian ini, maka perlu dilakukan validasi isi dan konstruk yang dilakukan oleh ahli yaitu Dosen Pendidikan Matematika Universitas Negeri Jakarta dan Guru Mata Pelajaran. Kemudian soal yang sudah divalidasi oleh ahli diberikan kepada kelas selain kelas eksperimen dan kelas kontrol sebagai uji validitas empiris dan menghitung reliabilitas instrumen. Hasil validasi isi, konstruk dan empiris menyatakan bahwa instrumen valid. Hal itu juga berlaku uji reliabilitas dengan koefisien 0,6 menggunakan Cronbach Alfa bahwa instrumen dapat dipercaya untuk digunakan sebagai tes.

\section{HASIL DAN PEMBAHASAN}

Penelitian ini mengambil data hasil post-test kemampuan berpikir kritis matematis siswa pada materi aturan sinus dan cosinus di dua kelas yaitu kelas X-IPS-3 sebagai kelas eksperimen dan X-IPS-2 sebagai kelas kontrol. Terdapat 72 siswa yang terbagi menjadi 36 siswa kelas eksperimen dan 36 siswa kelas kontrol. Kelas eksperimen melakukan pembelajaran dengan model pembelajaran kooperatif tipe ThinkPair-Square dengan pendekatan openended dan kelas kontrol menggunakan model pembelajaran konvensional.

Statistik deskriptif yang diperoleh dari hasil tes kemampuan berpikir kritis matematis siswa kelas eksperimen dan kelas kontrol disajikan sebagai berikut.

Tabel 2 Statistik Deskriptif Posttest Kemampuan Berpikir Kritis Matematis

\begin{tabular}{|c|c|c|}
\hline Statistik & $\begin{array}{c}\text { Kelas } \\
\text { Kontrol }\end{array}$ & $\begin{array}{c}\text { Kelas } \\
\text { Eksperimen }\end{array}$ \\
\hline Banyak & 36 & 36 \\
\hline
\end{tabular}

\begin{tabular}{|c|c|c|}
\hline Siswa & No & 32 \\
\hline $\begin{array}{c}\text { Nilai } \\
\text { Minimum }\end{array}$ & 94 & 94 \\
\hline $\begin{array}{c}\text { Nilai } \\
\text { Maksimum }\end{array}$ & 73 & 79,61 \\
\hline Rata-rata & 44 & 62 \\
\hline Jangkauan & 82 & 80 \\
\hline Modus & 66 & 114,24 \\
\hline Varians & 126,514 & 10,689 \\
\hline $\begin{array}{c}\text { Simpangan } \\
\text { Baku }\end{array}$ & 11,248 & 80 \\
\hline $\begin{array}{c}\text { Kuartil } \\
\text { Bawah }\end{array}$ & 74 & 88 \\
\hline $\begin{array}{c}\text { Kuartil } \\
\text { Tengah }\end{array}$ & 82 & \\
\hline Kuartil Atas & & \\
\hline
\end{tabular}

Berdasarkan tabel 2, nilai rata-rata tes kemampuan berpikir kritis matematis kelas eksperimen lebih tinggi dibandingkan nilai rata-rata tes kemampuan berpikir kritis matematis kelas kontrol. Sedangkan, hasil perhitungan simpangan baku pada kedua kelas, menunjukkan bahwa simpangan baku kelas eksperimen lebih rendah dibandingkan dengan kelas kontrol. Hal ini memiliki arti bahwa penyebaran nilai pada kelas eksperimen lebih homogen, sedangkan pada kelas kontrol lebih heterogen. Jadi, dapat dikatakan bahwa kemampuan berpikir kritis matematis siswa kelas kontrol lebih beragam dibandingkan kelas eskperimen.

Setelah itu, hasil post-test kemampuan berpikir kritis matematis siswa diberikan perlakuan uji normalitas dan uji homogenitas yang menunjukkan bahwa hasil post-test kelas eksperimen dan kelas kontrol berdistribusi normal dan homogen. Pengujian hipotesis pada pene-litian ini untuk menunjukkan apakah ada pengaruh model pembelajaran kooperatif tipe think-pair-square (TPSq) dengan pendekatan openended terhadap kemampuan berpikir kritis matematis siswa. Pengujian 
hipotesis dilakukan dengan menggunakan statistik uji-t dengan varians yang sama, yaitu pada taraf signifikansi $=0,05$ dan tolak $\mathrm{H}_{0}$ jika $t_{\text {hitung }} \geq t_{\text {tabel }}$ dengan $d k=n_{1+} n_{2}-2$ yang berarti rata-rata kemampuan berpikir kritis matematis siswa kelas eksperimen lebih tinggi dari kelas kelas kontrol. Hal ini menunjukkan bahwa terdapat pengaruh penerapan model pembelajaran kooperatif tipe think-pair-square (TPSq) dengan pendekatan open-ended terhadap kemampuan berpikir kritis matematis siswa.

Berdasarkan hasil perhitungan, diperoleh nilai $t_{\text {hitung }}=2,5564$ lebih tinggi dari nilai $t_{\text {tabel }}=1,667$, maka $\mathrm{H}_{0}$ ditolak. Hal ini dapat disimpulkan bahwa terdapat pengaruh yang signifikan penerapan model pembelajaran kooperatif tipe thinkpair-square (TPSq) dengan pendekatan open-ended terhadap kemampuan berpikir kritis matematis siswa SMA Negeri 48 Jakarta.

Penyebab kemampuan berpikir kritis siswa kelas eksperimen lebih baik dari kelas kontrol adalah adanya perbedaan proses pembelajaran di kelas kontrol dan kelas eksperimen. Pembelajaran pada kelas kontrol dan kelas eksperimen dilakukan selama enam kali pertemuan dan satu pertemuan untuk tes akhir kemampuan berpikir kritis matematis siswa. Siswa di kelas eksperimen diterapkan model pembelajaran kooperatif think-pair-square (TPSq) dengan pendekatan open-ended. Model pembelajaran kooperatif tipe think-pair-square dengan pendekatan open-ended dan model pembelajaran konvensional ini sama-sama memberikan kesempatan untuk siswa berdiskusi dan bertanya apabila ada kesulitan. Namun, model pembelajaran kooperatif tipe thinkpair-square dengan pendekatan open- ended memiliki perbedaan bila dilihat dari kegiatan inti pembelajaran. Masing-masing siswa berperan penting dalam proses menemukan penyelesaian yang tepat sehingga tidak hanya beberapa siswa yang aktif dalam pembelajaran seperti yang terjadi pada kelas kontrol dengan model pembelajaran konvensional.

Model pembelajaran kooperatif tipe TPSq memiliki tiga tahapan pembelajaran yaitu bekerja sendiri (think), bekerja berpasangan (pair) dan bekerja dengan empat orang (square). Di tahap think, siswa diberikan stimulasi masalah terbuka di awal sesuai dengan tahapan pendekatan open-ended. Masalah terbuka yang diberikan di awal pembelajaran sesuai dengan pokok bahasan pada pertemuan sebelumnya yang memiliki kaitan dengan pokok bahasan yang akan dibahas pada pertemuan tersebut. Masalah terbuka berguna untuk memberikan kesempatan kepada seluruh siswa merumuskan cara atau strategi yang tepat dalam menyelesaikan masalah sesuai dengan kemampuan masingmasing. Selanjutnya, siswa diberikan pengantar untuk pokok bahasan yang akan dibahas pada pertemuan tersebut.

Tahap think dilanjutkan kembali menggunakan Lembar Kerja Siswa (LKS) dengan beberapa masalah open -ended yang diberikan kepada setiap siswa. Pemberian LKS pada masingmasing siswa agar siswa dapat bekerja sendiri terlebih dahulu dalam menyelesaikan masalah yang ada. Tujuan lainnya agar seluruh siswa dapat berpatisipasi aktif selama proses pembelajaran berlangsung dan belajar untuk menyelesaikan masalah dengan pendapat sendiri. Tahapan selanjutnya yaitu bekerja berpasangan (pair), memungkinkan terjadinya perbedaan pendapat sehingga siswa bisa saling bertukar pikiran dan 
meluruskan pendapat sehingga mereka dapat menentukan penyelesaian masalah yang tepat. Begitupula dengan tahap square yaitu bekerja berempat, tahap ini lebih memungkinkan timbulnya perbedaan pendapat antar pasangan sehingga siswa berdiskusi kembali untuk menentukan penyelesaian masalah yang tepat. Proses berpikir secara bertahap ini sangat membantu siswa untuk mengembangkan kemampuan berpikir kritis matematis. Masingmasing tahap pada model pembelajaran kooperatif tipe thinkpair-square diberikan waktu selama 10 menit. Tahapan terakhir yang sejalan dengan pendekatan openended adalah diskusi untuk membahas penyelesaian dari masingmasing kelompok. Siswa bersama guru menarik kesimpulan beberapa penyelesaian yang dapat digunakan acuan pembelajaran pada materi yang dipelajari.

Berdasarkan uraian di atas, dapat disimpulkan bahwa apabila dilihat dari beberapa proses tahapan pembelajaran yang diterapkan pada kelas eksperimen dan kelas kontrol, keaktifan siswa dalam menyelesaikan masalah dan proses pengerjaan tugas atau masalah yang diberikan, wajar apabila terdapat perbedaan rata-rata kemampuan berpikir kritis matematis siswa antara kelas yang belajar menggunakan model pembelajaran kooperatif tipe think-pair-square dengan pendekatan open-ended dan siswa yang belajar menggunakan model pembelajaran konvensional.

\section{PENUTUP}

Berdasarkan hasil penelitian yang telah dilakukan, diperoleh kesimpulan bahwa terdapat pengaruh model pembelajaran kooperatif tipe think-pair -square dengan pendekatan openended terhadap kemampuan berpikir kritis matematis siswa SMA Negeri 48
Jakarta pada materi Aturan Sinus dan Cosinus. Hal ini terlihat dari rata-rata hasil tes kemampuan berpikir kritis matematis siswa yang belajar menggunakan model pembelajaran kooperatif tipe think-pair-square dengan pendekatan open-ended lebih tinggi daripada rata-rata hasil tes kemampuan berpikir kritis matematis siswa yang menggunakan model pembelajaran konvensional. Selain itu, hasil pengujian hipotesis dengan statistik uji-t dengan taraf signifikansi $a=0,05$ diperoleh hasil bahwa $t_{\text {hitung }}=$ $2,5564>t_{\text {tabel }}=1,667$ yang artinya tolak $\mathrm{H}_{0}$.

\section{DAFTAR PUSTAKA}

Budiman, H. (2011). "Peningkatan Kemampuan Berpikir Kritis dan Kreatif Matematis Siswa Melalui Pendekatan Pembelajaran Berbasis Masalah Berbantuan Software Cabri 3D." Tesis Universitas Pendidikan Indonesia, h. 1

Huda, M. (2011). Cooperative Learning: Metode, Teknik, Struktur, dan Model Penerapan. Yogyakarta: Pustaka Pelajar

Murniati, T. dkk. (2015). “Analisis Deskriptif Disposisi Berpikir Kritis Matematis Siswa Pada Pembelajaran Socrates Kontekstual." Jurnal Pendidikan Matematika UNILA 3(3), h.2

Nugroho, A. (2018). HOTS (Kemampuan Berpikir Tingkat Tinggi: Konsep, Pembelajaran, Penilaian, dan Soal-soal). Jakarta: PT. Grasindo, h. 18

Rafiah, H. dkk. (2018). "Berpikir Pseudo Mahasiswa PGSD Pada Operasi Bilangan Bulat." Math Didactic: Jurnal Pendidikan Matematika 4(1), 11-20 
Sucipto, "Pengembangan Ketrampilan Berpikir Tingkat Tinggi Dengan Menggunakan Strategi Metakognitif Model Pembelajaran Problem Based Learning", Jurnal Pendidikan, Vol.2, No.1, 2017, h.63

Sudjana. (2005). Metode Statistika. Bandung: Tarsito

Sugiyono. (2012). Metode Penelitian Kuantitatif, Kualitatif dan R\&D. Bandung, Alfabeta, h.77

Suwarma, D.M. (2009). Suatu Alternatif Pembelajaran Kemampuan Berpikir Kritis Matematika. Jakarta : Cakrawala Maha Karya

Syahbana, A. (2012). "Peningkatan Kemampuan Berpikir Kritis Matematis Siswa SMP Melalui Pendekatan Contextual Teaching and Learning." Edumatica 2(1). 45-47 